EPRA International Journal of Economic and Business Review-Peer Reviewed Journal Volume - 9, Issue - 9, September 2021 | e-ISSN: 2347 - 9671| p- ISSN: 2349 - 0187

\title{
TRUST AND PURCHASE INTENTION ON ONLINE SHOPS AMID COVID 19 PANDEMIC: AS BASIS FOR REGULATORY POLICY
}

\author{
Norberto M. Secretaria ${ }^{1}$, Amelia Girly L. Aranas' ${ }^{2}$, Christina Y. Pacubas ${ }^{3}$, \\ Leovigilda L. Bithay ${ }^{4}$ \\ ${ }^{1,2,3,4}$ College of Management and Entrepreneurship, Cebu Technological University
}

\begin{abstract}
DOI No: 10.36713/epra8480

Article DOI URL: $\underline{\text { https://doi.org/10.36713/epra8480 }}$

Online shops are inevitable. It is the future of commerce. The convenience it offers surpasses all previous platforms of exchange combined. During this pandemic, online shops have seen a tremendous business opportunity as it has become the only option to acquire necessities for survival amid lockdowns. The rise in the number of online shops is like mushrooms, sprouting everywhere, where there is almost no chance of knowing which are bogus and legitimate. Hence, skeptical minds begin to question the security of online purchases. Many fears, but some are confident. This paper presents the primary demographical distribution of the online customers, preferred payment options, level of trust in online shops, and, more importantly, shows customers' purchase intentions towards different shop characteristics. It was concluded that the ecommerce industry in the country enjoys a relatively high trust rating among its customers. And that customers have higher purchase intention to shops that offer cash on delivery, fast delivery time, responsive customer service, accessible to both web and apps, and sell cheap products.
\end{abstract}

\section{INTRODUCTION}

The COVID 19 pandemic has undoubtedly caught the world off-guard. It has rendered the economies of the world on hold(Koh, 2020). Many of those that are actively participating in the workforce suddenly found themselves working from home(Looi, 2020). It has, in effect, created a whole new system. In this new world order, people's demands are no longer dependent on traditional brick and mortar stores, supermarkets, grocery stores, and convenience stores, and the like. The pandemic has made a different battleground in business, the internet (Alfonso et al., 2020; Tran, 2021).

Like many other countries globally, the Philippines imposed almost draconian lockdowns that actively disallows anyone from going outside. This measure severely affected the lives of millions of Filipinos, most especially in the quest to have access to primary and essential needs(Mendoza, 2020). However, this kind of heavy restriction of a movement seemingly appears to be a blessing in disguise, especially to those 
who wish to enter the business world through the internet. The pandemic has induced a heavy volume of online purchases as it is the only way to access primary needs and other necessities amid massive lockdowns.

Purchases online primarily comprise basic sleep necessities, kitchen utilities, gadgets, and food.

\section{Issues and Concern}

With the rise of online customers comes the increase of those perpetrators of evil that seek to take the situation's opportunity. Reports have surfed that many Filipinos fell victims in the hands of bogus sellers and scammers who only took their money but did not deliver the products (Atienza \& Tabuena, 2021). In some cases, incorrect orders arrive, with little or no options for order corrections and return. Many of these scams happened even on the most trusted online platforms.

Several issues in online shopping are the quality of the product sold online, the accuracy of the labels, accuracy of sizes, truthfulness of the product, the trustworthiness of the sellers, unavailability of cash on delivery options, food handling, and many others.

While it is true that online shops are a relatively young industry in the Philippines and Southeast Asia, assurance of satisfying purchases would be an excellent enabler for more excellent opportunities in the field of online commerce (Tzeng et al., 2021). E-commerce in the Philippines still has to expand into several sectors, including other basic food necessities and agricultural products(Secretaria, 2019a, 2019b). This paper provides a clearer understanding of the current state of affairs in the Philippines e-commerce industry by determining the level of trust and purchase intentions of actual and potential customers. This paper also presents several strategies employed by the respondents to prevent themselves from falling into scams and other illegal online activities and fraud. The primary objective of this paper was to determine the following: whether or not there are significant many who fell victims to bogus sellers online, the strategies used by the respondents in determining the legitimacy of online sellers, the perceived level of trust in different aspects of online shops, the most occurring problem when ordering online, perceived purchase intentions based on shop characteristics and services, and the most preferred online platform to order products.

\section{METHODOLOGY}

This research adopted a descriptive survey method to actualize the objective of this study. This study used primary data collected through the use of survey questionnaires. The study was conducted in Cebu, Philippines, where participants are residents. The questionnaires consist of different significant parts: purchase intentions on a particular shop based on various characteristics and service features, perceived level of trust among respondents towards online shops, strategies used to verify the authenticity of the sellers, and the most trusted online shops utilized, by the participants. There were fifty respondents in this study. All were selected in multi-staged pure random sampling technique. Considering basic health protocols imposed during this pandemic, the researchers opted for the survey online using google forms. After collecting the data, the researchers coded and analyzed the data based on the research objectives.

\section{RESULTS AND DISCUSSION}

Descriptive Analysis on Demographic Profiles and other relevant information

Figure 1 presents the gender distribution of the respondents in this study. There are $94.1 \%$ female respondents and only around $5.9 \%$ male. This finding is significant because this stresses the fact that women are the most susceptible to online purchases. This result reinforces that social media algorithms highly target women to receive specialized ads resulting in purchasing.

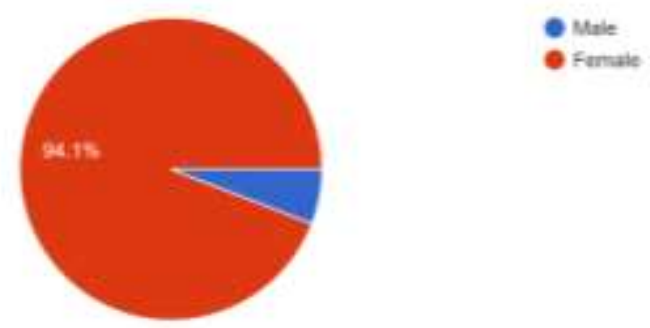

Figure 1: Gender 
Figure 2 reveals the civil status of the respondents, which indicates that $58.8 \%$ are single and $41.2 \%$ married. The data means that there are more single women in the market for online shops. From the perspective of marketing management, primarily on promotions and marketing communication, this result is excellent and helpful for targeting these specific demographics. In line with the marketing principle of market segmentation, this information is a relevant fact that can target single women who have purchasing

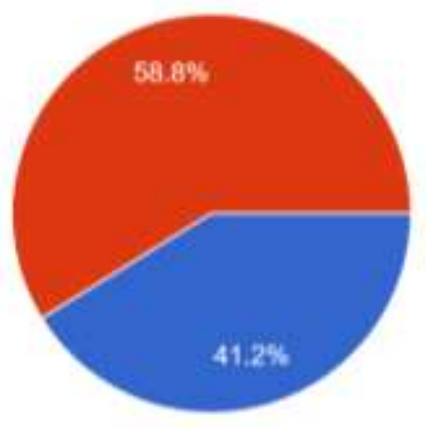

power and have the urge to purchase online (Müller \& Hamm, 2014). The implication of this data to the ecommerce industry in the Philippines is that they have to shift the focus on providing single women a satisfying experience in terms of the overall online purchase transaction(Jaiswal et al., 2020). Advertising may also be targeted heavily on this critical demographic considering this tangible result (Kimiagari et al., 2019).

Figure 2: Civil Status

Figure 3 reveals the respondents' educational attainment where there is $70.6 \%$ college level or graduates. This result indicates that the supermajority of the respondents has proper education, at the least, college-level education. Though it is not always the case, however, education presumes purchasing power.

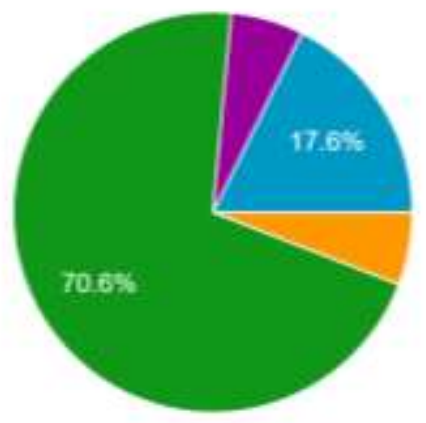

Hence this means that significant many of the respondents are women who are single and relatively well educated. These key demographics mean a lot to the e-commerce industry as this represents a business opportunity.

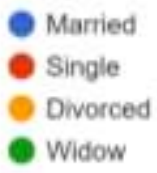

\section{Figure 3: Educational Attainment}

According to the world bank and the Philippine Statistics Authority, the poverty line in the Philippines is at around 10,500 Pesos per family in one month(PSA, 2017). Figure 2 reveals that the respondent in this study does not live below the poverty line. The data shows that $47.1 \%$ earns $10,001-20,000$ Php every month, making the respondents fall under the LowerMiddle-Income class in social stratification. Purchasing power is one of the essential aspects of determining a target market. This requirement cannot be left out, as paying is a necessary element in business transactions. The implication of this data is a promising future for the e-commerce industry in the Philippines. The Philippines' e-commerce industry was valued at USD 3 Billion in 2019, and is expected to reach USD 12 Billion in 2025. This expectation was just reinforced by the data collected in this research. 


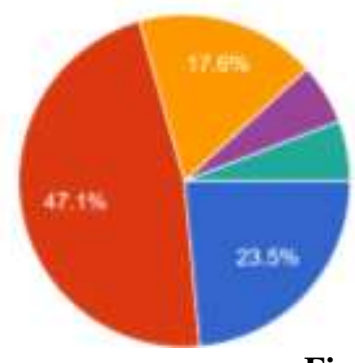

Figure 4: Income

The advent of modern technology revolutionized the world by enabling communication to flow over the speed of light and changed the way the world behaves and makes purchases. Technology is so remarkable that even payment of purchases no longer requires the position of actual fiat money or any goods with economic value. The digitized version of the banking sector and other financial institutions and providers allows tech-savvy individuals to transact business and pay online (Liao \& Yang, 2020). Only these few years, the Philippines has been slowly adopting revolutionary technology to change the way the world lives. The ability to pay online. The current pandemic pushed this has in effect pushed this revolutionary technology into the breaking point that

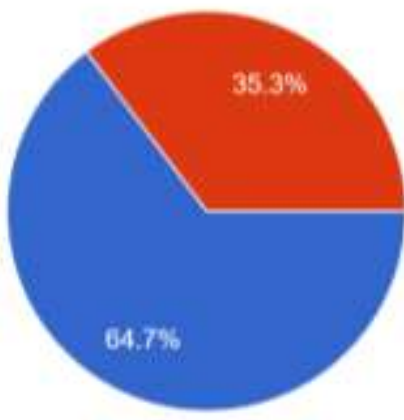

even the skeptics were eventually convinced using the same. Despite the rapid propagation of online payment platforms, many still fear the security of the money stored online. The respondents in this study opted to pay their purchase transactions online, with $64.7 \%$ admitted online payment methods. Only $35.3 \%$ of the respondents choose to pay online transactions with actual cash. This data implies that there is still a broader room for the online payment firms to expand their services as many still do not use the online payment platforms. The challenge, however, is to convince skeptical minds over the security of the hardearned money in the realm of the digital world (Wang, 2020).

\section{Figure 5: Online Payment Options}

Despite current regulations and criminalization of online fraud and other analogous circumstances under the Philippine Anti-Cyber Crime Law of 2012 or Republic Act No 10175, quite a number of the respondents in this study have transacted to a bogus or a scam seller online. $17.6 \%$ of the respondents have transacted a bogus seller. The regulatory implication with this result is that the concerned government agencies under which online commerce belongs have to increase vigilance and visibility(Pamela et al., 2020). This move aims to aid the victims of these evil perpetrators and educate the purchasing public to be alert and ready to recognize red flags even at the beginning of an online transaction. 


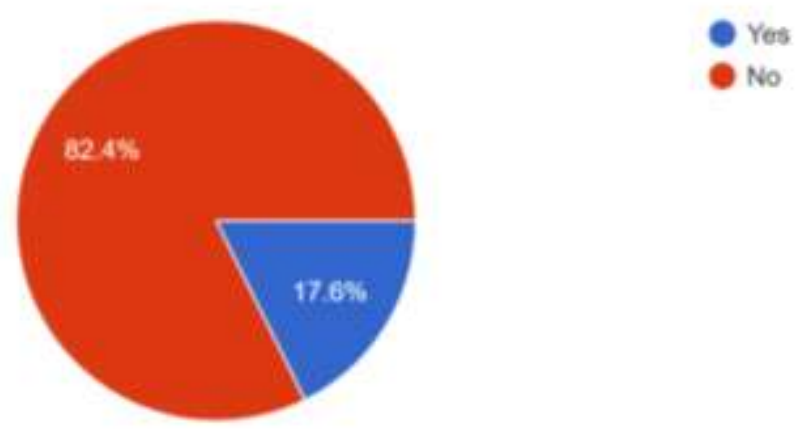

Figure 6: Transacted Bogus Sellers

While it is true that the enactment of the Philippine Anti-Cyber Crime Law of 2012 or Republic Act No. 10175 and other laws governing e-commerce and online conduct, the reality remains clear, that the long arm of the law finds it hard to seek justice against victims of online criminal perpetrators hiding in the cloak of anonymity. It is not surprising that $45.5 \%$ of those victims of online scams have fear for their security. The fear is fueled by the fact that these scammers and evil perpetrators online have the personal and confidential information provided to them out of trust and confidence. Although the dissemination of this confidential information without the owner's prior consent constitutes a violation of the Data Privacy Law of the Philippines or Republic Act 10173, nothing can stop these criminals from conducting surveillance

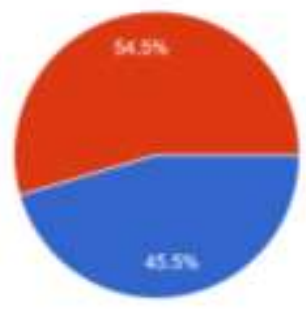

Figure 7: Fear of security

Purchasing online during this pandemic has become a norm. While making purchases online, users must always be alert for any red flags that give clues to bogus sellers and scammers. The respondents were asked for strategies to ensure that they were not transacting with scammers, and these are the results. Most of the respondents prefer reading reviews of a particular store or online shop to check for any customers' reviews and double check for any form of a negative review posted in a specific online store (Fu et al., 2020; Tran, 2020; Ventre \& Kolbe, 2020). Then, this is followed by cross-checking other stores for any alternative price offering of the same product, then and or premeditating more crimes against a victim (Cheing, 2021). Hence there is this fear that bogus sellers who possess private and confidential information might come after them. The implication of this data under Figure 7 on fear of security is within the purview of public administration, in which public administrators must serve and protect the interest of the public and its constituents. In the eyes of an excellent public servant, the arms of the law must be implemented even to the deepest part of online anonymity. This is for the promotion and welfare of the consuming public. The regulatory implication with this data result is the possible creation of a commission or a body that seeks to investigate and regulate online transactions and prosecute violators of the law.

followed by star ratings and personally calling the shops. The data implies a positive development in the e-commerce industry, as it projects an informed consumer. The data means that the users of online purchasing apps know exactly what to do in order to ensure that they are not transacting with bogus buyers. Though these steps mentioned by the respondents are not fool-proof or perfect in any manner, the reality remains that smaller steps to protect one's interest online are enough to deter evil-doers seeking to victimize online users. Table 1 presents the summary of the results. 
Table 1. Strategies for avoiding bogus sellers

\begin{tabular}{|l|l|l|}
\hline Strategies & f & Percentage \\
\hline Cross-checking product prices & 25 & $50 \%$ \\
\hline Reading reviews of other customers & 44 & $88.00 \%$ \\
\hline Looking at star ratings & 19 & $38.00 \%$ \\
\hline Calling the shops & 10 & $20.00 \%$ \\
\hline Transacting with flagship stores only & 4 & $8.00 \%$ \\
\hline Shops that allows COD & 4 & $8.00 \%$ \\
\hline Check the profile of the sellers & 4 & $8.00 \%$ \\
\hline
\end{tabular}

\section{Trust and Purchase Intention}

Trustworthiness is one of the essential elements of an effective seller. Trust is the primary driver of purchase decisions. In the traditional way of a business transaction, trust is easily conveyed to the target customer by communicating both verbal and nonverbal means. You can also send a sense of security and a feeling of comfort through the proper way of communicating with eye contact and attentive listening. However, in the modern context of selling, communication is devoid of any form of emotion. It is up to the receiver on how the message is interpreted. The modern business landscape complicates business communication and makes value communication and value delivery more challenging.

Value affects purchase decisions (Kaur et al., 2021). Hence it is a very important aspect in the business sector to communicate and deliver value to the customers. It is basic in the modern business landscape that the more value the customer receives in any form, the higher the likelihood of repeat purchases(Dagevos $\&$ van Ophem, 2013). If one customer is well cared for, the higher the probability of making one customer a patron. One way of making the customer feel the sense of being valued is the communicate trust. Hence, in this case, the respondents were asked how high their trust is that the online seller they transacted with will comply and deliver the promised good at the desired timeline and the agreed or advertised quality. The result is skewed to the trustworthy spectrum at a rate of 1 to 10 , 10 being highly trustworthy, and one being not trustworthy, where $20 \%$ scored $10,20 \%$ scored $8,30 \%$ scored 7. This data implies a promising future for the ecommerce industry. Though some have encountered difficulties purchasing products online, it is still undeniable that online shops enjoy a high trust rating.

Table 2. Shop characteristics and corresponding perceived rate of intention to purchase

\begin{tabular}{|l|r|}
\hline Shop Characteristics & Rating \\
\hline Cash on delivery & 9.29 \\
\hline Delivers on time & 8.41 \\
\hline Responsive customer service & 8.29 \\
\hline Web and App platform & 7.82 \\
\hline Cheap Products & 7.41 \\
\hline App-based only & 6.59 \\
\hline Web-based only & 6.24 \\
\hline Online payment only & 6.12 \\
\hline Pay first before delivery & 4.65 \\
\hline Concealed pricing & 4.53 \\
\hline
\end{tabular}

Based on the findings as presented in Table 2, it can be clearly understood that customers find the online purchase's security when the shops offer cash on delivery (Anjum \& Chai, 2020; Hamed \& El-Deeb, 2020). Though as discussed above, many of the respondents are willing to pay online as they have the means to do so. The data revealed further that, customers take specific note of the importance of delivery time, responsive customer service, accessibility of the shop to both web-based and appbased platform that sells the cheap product. For sellers, the data reveals that customers do not prefer to buy in shops that do not provide the exact prices of the goods and services and or demand the customer to pay first before delivering the goods and services. This simple survey result has enormous implications for those who are already existing online sellers and those who want to sell something online. Customers have higher 
purchase intention to shops that offer cash on delivery, fast delivery time, responsive customer service, accessible to both web and apps, and sell cheap products(Hamed \& El-Deeb, 2020).

\section{CONCLUSION}

It is not a trivial fact that trust plays a significant role in the purchase decision or any form of judgment in favor of one particular thing. Through the findings of the study is was concluded that the young e-commerce industry in the Philippines enjoys relatively high trust and confidence on the part of the purchasing public. And that, while it is true that there were many instances that illegitimate and bogus sellers have victimized several customers, the truth of the matter is, there is a kind of optimism that through vigilance and the application of basic strategies of double-checking and cross-comparison of sellers, one can still find satisfying purchases through legitimate online transactions. As to the purchase intentions based on different shop characteristics, it was concluded that customers have higher purchase intention to shops that offers cash on delivery, fast delivery time, responsive customer service, accessible to both web and apps, and sell cheap products. Finally, there is a need to establish regulations that protect buyers and sellers online to promote harmony and mutual growth and propel forward for the promotion of this thing of the future, the e-commerce industry.

\section{RECOMMENDATION}

Based on the conclusions, it is highly recommended that online shops focus on providing fast and reliable service to their customers. It is also advised on the part of the authority to establish a regulatory body to protect both buyers and sellers online to ensure that harmony occurs in the quest towards collective progress. Finally, the authors suggest that authorities adopt the regulatory outline presented in this paper.

\section{REGULATORY OUTLINE}

With the country's current cyber security situation and the rise of online shops, it is necessary to have a specific regulatory body that exercises authority over online transactions, address, investigate, and resolve issues and disputes regarding all online purchase transactions. The regulatory commission, body, or authority shall have but not be limited to the following mandates:

1. Regulates and monitors all online transactions involving the exchange of goods and services.

2. Conduct accreditation of online shops, verifies processes, and provide accreditation ratings. It would be illegal to sell online without such accreditation from this body.
3. Receives customer complaints and investigate the same for the prosecution of any violator of the law or perform mediations for extrajudicial settlements

4. Suspend or disallow online shops from operations when necessary

5. Publish and maintain a list of accredited and legitimate online shops within the country. This requires providers of platforms to keep in touch with the regulatory authority to monitor all sellers online.

\section{REFERENCES}

1. Alfonso, V., Boar, C., Frost, J., Gambacorta, L., \& Liu, J. (2020). Online appendix - E-commerce in the pandemic and beyond.

2. Anjum, S., \& Chai, J. (2020). Drivers of Cash-onDelivery Method of Payment in E-Commerce Shopping: Evidence From Pakistan: Https://Doi.Org/10.1177/2158244020917392, 10(3). https://doi.org/10.1177/2158244020917392

3. Atienza, M. A., \& Tabuena, A. C. (2021). The Impact of COVID-19 Pandemic on Managerial Accounting and Its Adjustments in Financial Markets. International Journal of Business, Technology and Organizational Behavior (IJBTOB), 1(4), 287-296. https://doi.org/10.52218/IJBTOB.V1I4.109

4. Cheing, D. (2021). Applicability of Information Governance for Data Privacy Compliance in the Education Sector. https://www.dlsu.edu.ph/wpcontent/uploads/pdf/conferences/researchcongress-proceedings/2021/HCT-12.pdf

5. Dagevos, H., \& van Ophem, J. (2013). Food consumption value: Developing a consumercentred concept of value in the field of food. British Food Journal, 115(10), 1473-1486. https://doi.org/10.1108/BFJ-06-2011-0166

6. $\quad F u, H .$, Manogaran, G., Wu, K., Cao, M., Jiang, S., \& Yang, A. (2020). Intelligent decision-making of online shopping behavior based on internet of things. International Journal of Information Management, 50, 515-525. https://doi.org/10.1016/J.IJINFOMGT.2019.03.010

7. Hamed, S., \& El-Deeb, S. (2020). Cash on Delivery as a Determinant of E-Commerce Growth in Emerging Markets. Https://Doi.Org/10.1080/08911762.2020.1738002, 33(4), 242-265. https://doi.org/10.1080/08911762.2020.1738002

8. Jaiswal, D., Kaushal, V., Singh, P. K., \& Biswas, A. (2020). Green market segmentation and consumer profiling: a cluster approach to an emerging consumer market. Benchmarking: An International Journal, 28(3), 792-812. https://doi.org/10.1108/BIJ-05-2020-0247

9. Kaur, P., Dhir, A., Talwar, S., \& Ghuman, K. (2021). The value proposition of food delivery apps from the perspective of theory of consumption value. International Journal of Contemporary 
Hospitality Management, 33(4), 1129-1159. https://doi.org/10.1108/IJCHM-05-2020-0477

10. Kimiagari, S., Keivanpour, S., \& Haverila, M. (2019). Developing a high-performance clustering framework for global market segmentation and strategic profiling. Https://Doi.Org/10.1080/0965254X.2019.1628099, 29(2), $93-116$. https://doi.org/10.1080/0965254X.2019.1628099

11. Koh, D. (2020). COVID-19 lockdowns throughout the world. Occupational Medicine, 70(5), 322-322. https://doi.org/10.1093/OCCMED/KQAA073

12. Liao, S. H., \& Yang, L. L. (2020). Mobile payment and online to offline retail business models. Journal of Retailing and Consumer Services,57,102230. https://doi.org/10.1016/J.JRETCONSER.2020.1022 30

13. Looi, M.-K. (2020). The covid-19 yearbook: worldleadersedition.BMJ,371.https://doi.org/10.11 36/BMJ.M4728

14. Mendoza, R. U. (2020). Economics of Lockdown: Insights on Building Back Better in Post-Pandemic Philippines. 2020.2 https://thinkasia.org/handle/1 1540/12237

15. Müller, H., \& Hamm, U. (2014). Stability of market segmentation with cluster analysis - A methodological approach. Food Quality and Preference, 34, 70-78.

https://doi.org/10.1016/j.foodqual.2013.12.004

16. Pamela, A., Fabe, H., \& Zarcilla-Genecela, E. (2020). The Philippines' cybersecurity strategy. Routledge Companion to Global Cyber-Security Strategy, 315-324. https://doi.org/10.4324/9780429399718-26/LINEFIRE-TOBIAS-BURGERS-MORITZ-HELLMANNSCOTT-ROMANIUK

17. PSA. (2017). Philippine Statistics Authority | Republic of the Philippines. https://psa.gov.ph/poverty-pressreleases/nid/120251

18. Secretaria, N. M. (2019a). Product Marketing Systems: the Challenge of Poverty and the Culture of Resistance Against Technological Change. Theoretical \& Applied Science, 74(06), 318-324. https://doi.org/10.15863/tas.2019.06.74.40

19. Secretaria, N. M. (2019b). THE E-COMMERCE REVOLUTION: STATUS, AWARENESS AND DEMOGRAPHICS OF FARMERS IN CEBU CITY. Theoretical \& Applied Science, 74(06), 101-109. https://doi.org/10.15863/TAS.2019.06.74.7

20. Tran, L. T. T. (2020). Online reviews and purchase intention: A cosmopolitanism perspective. Tourism Management Perspectives, 35, 100722 https://doi.org/10.1016/J.TMP.2020.100722

21. Tran, L. T. T. (2021). Managing the effectiveness of e-commerce platforms in a pandemic. Journal of Retailing and Consumer Services, 58, 102287. https://doi.org/10.1016/J.JRETCONSER.2020.1022 87

22. Tzeng, S. Y., Ertz, M., Jo, M. S., \& Sarigöllü, E. (2021). Factors affecting customer satisfaction on online shopping holiday. Marketing Intelligence \&amp; $\quad$ Planning, 39(4), 516-532. https://doi.org/10.1108/MIP-08-2020-0346

23. Ventre, I., \& Kolbe, D. (2020). The Impact of Perceived Usefulness of Online Reviews, Trust and Perceived Risk on Online Purchase Intention in Emerging Markets: A Mexican Perspective. Https://Doi.Org/10.1080/08961530.2020.1712293, 32(4), 287-299. https://doi.org/10.1080/08961530.2020.1712293

24. Wang, C. (2020). The Behavioral Sign of Account Theft: Realizing Online Payment Fraud Alert. 